\title{
Measurement of Volatilized Mercury by a Mini-System: a Simple, Reliable and Reproducible Technique
}

\author{
Luciana Cursino $^{1}$, Silvânia V. M. Mattos ${ }^{2}$, Nilton O. Silva ${ }^{2}$, Edmar Chartone-Souza ${ }^{1}$ and \\ Andréa M. A. Nascimento ${ }^{1 *}$ \\ ${ }^{1}$ Departamento de Biologia Geral; Instituto de Ciências Biológicas; Universidade Federal de Minas Gerais; \\ amaral@icb.ufmg.br; Av. Antônio Carlos, 6627; 31.270-901; Belo Horizonte - MG - Brazil. ${ }^{2}$ Setor de \\ Contaminantes Metálicos; Instituto Octávio Magalhães; Fundação Ezequiel Dias
}

\begin{abstract}
A simple and easy new technique for volatilized mercury determination in biological systems was developed. This technique is fast and sensitive and can overcome the problems that arise due to the extremely low readings during the measurements and reproducibility in biological material (bacteria). It measures directly the volatilized metallic mercury of bacteria by means of a chemical adsorbent in a coupled mini-system, as a modified technique for mercury in air analysis. It is potentially of interest to the bioremediation and bacterial mercury resistance communities
\end{abstract}

Key words: Bacteria, biological system, measurement, mercury, volatilization

\section{INTRODUCTION}

Mercury is one of the most toxic metals in the environment, and has no biological function. However, since bacteria are very likely to be confronted with toxic $\mathrm{Hg}^{+2}$ concentrations, mercury resistance determinants (mer) are widespread. This mechanism is of interest since it codes proteins for transport and reduction of mercuric ions in Gram-negative bacteria. (Silver and Phung, 1996; Quian et al, 1998; Nies, 1999). Resistance to mercury is based on particularities of the metal such as its redox potential, vapor pressure, and low melting and boiling point. Thus, bacterial cells are able to reduce $\mathrm{Hg}^{+2}$ to $\mathrm{Hg}^{0}$, which does not remain inside the cell with the potential of becoming oxidized again, but leaves the cell by passive diffusion (Nies, 1999).
The use of bacterial biomass for metal removal from contaminated environment is a promising technology. However, the determination of mercury in biological material has always proved problematic because of the difficulty of complete oxidation of the matrix, with quantitative retention of the metal. Specific oxidation techniques developed to destroy organic material prior to mercury analysis are incapable of fully oxidizing some materials such as culture media. These difficulties are due to the low temperature required during the oxidation stage to avoid mercury volatilization and to the extremely low mercury levels detected in such a complex matrix (Watling, 1977; Vecchio, 1998).

There are few techniques to study bacterial mercury volatilization. Usually, the ability of a specific strain to volatilize radioactively labeled

* Author for correspondence 
$\mathrm{Hg}^{+2}\left({ }^{203} \mathrm{Hg}\right.$ half-life of 46 days $)$ is tested, followed by mercury measurement with a type of scintillation counter, an expensive and laborious technique (Scottel et al., 1974; Kusano et al., 1990). A screening method is also available, which uses X-ray film spots in the analysis, using the reduction of $\mathrm{Ag}^{+}$emulsion with mercury vapor, but this is not a really a quantitative technique (Nakamura et al., 1999).

In a previous report, a genetically engineered Escherichia coli strain was constructed to express simultaneously two systems (mer and glutathione S-transferase) which may be used to remove $\mathrm{Hg}^{+2}$ (Cursino et al., 2000). The present report describes the construction of a mini-system involving modifications of a technique used for the determination of mercury in air using a chemical adsorbent for the determination of mercury volatilized by this bacterial strain.

\section{MATERIALS AND METHODS}

\section{Experimental approach}

The experiments were designed to allow the control of both the biological system (bacteria) and the chemical system (soluble constituents). The strains were grown and prepared for the volatilization assay as described by Cursino et al. (2000).

\section{Mini-system apparatus}

A glass mini-system apparatus was built to measure the total mercury volatilized by the tested strains. It consisted of a container with a sealed inner chamber and an air outlet equipped with an appropriate metal vapor outlet containing silica gel that retains water vapor and a vacuum pump which permits the transport of all mercury vapor through the adsorbent cartridge, a Cerulite $\AA_{200}$ Hopcalite ${ }^{\circledR}$-type tube- All glass junctions were sealed with Teflon®.

\section{Mercury analysis}

Mercury concentration in the Cerulite ${ }^{\circledR}$ tube was measured in the soluble form with an atomic absorption Analyst 300 spectrophotometer using the cold vapor Mercury Analysis System accessory FIAS 400 from Perkin Elmer (AASCV). Total mercury in acid solutions was quantified by NIOSH-recommended procedures for mercury in air analysis (NIOSH, 1994).

\section{Glassware}

All glassware employed were previously immersed in a $1.6 \mathrm{M} \mathrm{HNO}_{3}$ batth for 24 hours, rinsed in purified water, and then sterilized by autoclaving prior to the analysis.

\section{Reagents}

All reagents used were free-from-mercury grade and the water was purified with a MilliQ apparatus from Millipore ${ }^{\circledR}$.

\section{RESULTS AND DISCUSSION}

We first tried to quantify the capacity of bacterial strains to volatilize metallic mercury directly in the culture medium by AAS-CV and to calculate the content of volatilized mercury by the difference of the mercury concentration added and found after the period of incubation with the bacterial strains (data not shown). The AAS-CV technique is well known and relatively inexpensive. But the culture medium is a complex organic matrix requiring hard conditions such as high temperature prior to mercury analysis and considering the high capacity of mercury to be lost by volatilization. In addition to extremely low readings during the measurements and reproducibility this technique has failed (data not shown). To overcome these difficulties we developed a different procedure to measure directly the volatilized metallic mercury content, without any matrix interference or digestion steps, by means of a simple apparatus which was called mini-system (Fig. 1).

After optimization, the procedure proved to be very fast and simple, avoiding all the difficulties involved in the acid digestion of the samples. In this method is only necessary to solubilize the Hopcalite ${ }^{\circledR}$ tube content and to perform mercury analysis by AAS-CV.

Cerulite ${ }^{\circledR}$ is a copper compound of high sensitivity and specificity in retaining mercury. The Hopcalite ${ }^{\circledR}$ tube is currently used coupled to individual air pumps for the evaluation of mercury exposure in the work place environment (McCammon et al., 1980; OSHA, 1987). 


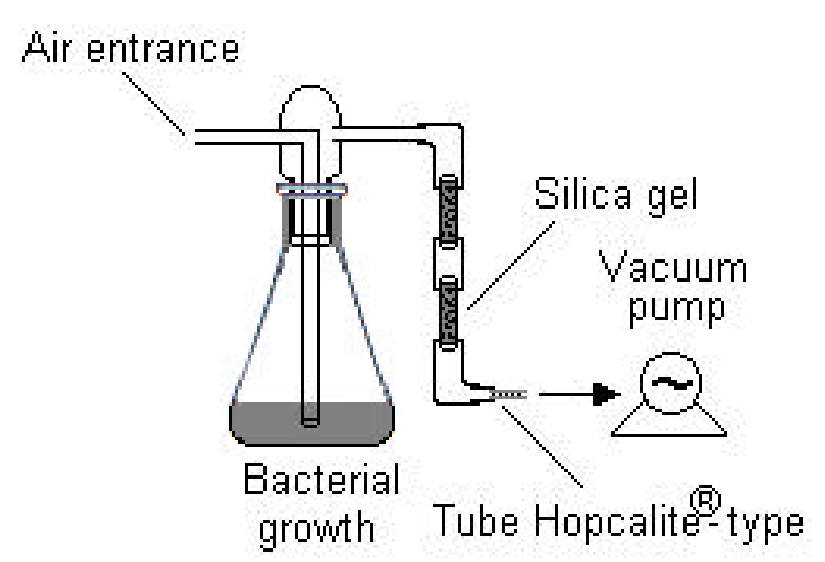

Figure 1 - Complete mini-system apparatus.

In the present study we used its property of retaining mercury, but coupled to a settling vessel containing bacterial growth in the presence of 15 $\mu \mathrm{g} / \mathrm{ml}$ inorganic mercury $\left(\mathrm{HgCl}_{2}\right)$ concentration. The device directly quantifies the content of metallic mercury produced (Cursino et al., 2000). Two intermediary columns containing desiccating material (silica gel) were coupled to the device to retain air flux humidity before passing the sample through the Hopcalite ${ }^{\circledR}$ tube. This proved to be necessary after the first experiments, when we observed the interference of humidity with the dryness and efficiency of the adsorbent, and solved the problem. After the glass junctions and connections were completely sealed, the evaluation of the content of mercury volatilized by bacterial strains became a direct process without any difficulties.

The quantitative results of the volatilized mercury obtained using different genetically engineered strains have been reported by Cursino et al. (2000). In the cited study, the mercury content detected showed to be as sensitive as any method using AAS-CV to determination of mercury in non-biological material. The mini-system procedure presented advantages because reduced several sources of errors such as interference, introduction of contaminants, and reading disturbances, since the tubes were stable and kept in a dark dry place, and the readings of an experiment could be scheduled for the same day and under the same conditions.

It should be emphasized that this device permits direct readings of metallic mercury produced during bacterial growth, and the process is simple and fast, basically consisting of acid dissolution of the adsorbent, free from the media organic material. The comparative characteristics of the mini-system and of some other techniques used to measure volatilized mercury are shown in Table 1 . Using this simple to operate mini-system technique, reliable and reproducible results were obtained.

Table 1 - Comparative characteristics of the mini-system and some other techniques to measure volatilized mercury.

\begin{tabular}{cccc}
\hline Techniques & $\begin{array}{c}\text { Time required } \\
\text { (hours) }\end{array}$ & $\begin{array}{c}\text { *Price per sample } \\
\text { (US\$) }\end{array}$ & Detection limit \\
\hline $\mathrm{Hg}^{+2}$ labeled radioactively/ & $\sim 10$ & $\sim 90$ & $0.03 \mu \mathrm{g} / \mathrm{ml}$ \\
scintillation counter & $\sim 7$ & $\sim 10$ & $>0.5 \mu \mathrm{g} / \mathrm{ml}$ \\
X-ray film spots/ $\mathrm{Ag}^{+}$emulsion & $\sim 2$ & $\sim 10$ & $0.03 \mu \mathrm{g} \mathrm{per} \mathrm{sample}$ \\
Mini -system/AAS & &
\end{tabular}

\section{ACKNOWLEDGEMENTS}

This work was supported by CNPq, FUNED and FAPEMIG.

\section{RESUMO}

Uma metodologia simples foi desenvolvida para medir o mercúrio volatilizado em um sistema biológico. Esta técnica é rápida, sensível e pode superar as dificuldades freqüentemente observadas em material biológico tais como, leituras extremamente baixas e a sua reprodutibilidade. Este sistema mede diretamente por meio de um adsorvente químico acoplado a um mini-sistema o mercúrio metálico volatilizado pela bactéria. Para isto, a metodologia para a análise de mercúrio em amostras de ar foi modificada. Esta técnica é de interesse para a biorremediação e para o estudo de comunidades bacterianas resistentes ao mercúrio. 


\section{REFERENCES}

Cursino, L.; Mattos, S. V. M.; Azevedo, V.; Galarza, F.; Bucker, D. H.; Chartone- Souza, E. and Nascimento, A. M. A. (2000), Capacity of mercury volatilization by mer (from Escherichia coli) and glutathioneStransferase (from Schistosoma mansoni) genes cloned in Escherichia coli. Sci. Total Environ., 261, 109-113.

Kusano, T.; Ji, G.; Inoue, C. and Silver, S. (1990), Constitutive synthesis of a transport function encoded by the Thiobacillus ferrooxidans merC gene cloned in Escherichia coli. J. Bacteriol., 172, 2688-2692.

McCammon, C. S.; Edwards, S. L.; Hull, R. D. and Woodfin, W. J. (1980), A comparison of four personal sampling methods for the determination of mercury vapor. Am. Ind. Hyg. Assoc. J., 41, 528-531

Nakamura, K.; Naruse, I. and Takizawa ,Y. (1999), A new mass screening method for methylmercury poisoning using mercury-volatilizing bacteria from Minamata Bay. Ecotoxicol. Environ. Saf., 44, 100-104.

Nies, N. H. (1999), Microbial heavy-metal resistance. Appl. Microbiol. Biotechnol., 51, 730-750.

NIOSH - National Institute for Safety and Health (1994), Manual of Analytical Methods In: Nicholson, K. R. and Steele, M. R. Cold vapor mercury analysis system Method number 6009. Ed. Data Chem. Laboratories, Inc., Salt Lake City, Utah, under NIOSH contract No. 200-87-2533, $4^{\text {th }}$ ed., issue 2. pp. 255.

OSHA - Occupational Safety and Health Administration (1987), Analytical Laboratory. In: Mercury in workplace atmospheres (hydrar tubes). OSHA-SLTC Method No. 45H, inorganic section, Ed OSHA, Salt Lake City, UT.

Quian, H.; Sahlman, L.; Eriksaon, P. O.; Hambraeus, C.; Edlund, U. and Sethson, I. (1998), NMR Solution structure of the oxidized form of Mer P, a mercuric ion binding protein involved in bacterial mercuric ion resistance. Biochemistry, 37, 9316-9322.
Schottel, J.; Mandal, A.; Clark, D.; Silver, S. and Hedges, R. W. (1974), Volatilization of mercury and organomercurials determined by inducible R-factor systems in enteric bacteria. Nature, 251, 335-337.

Silver, S. and Phung, L. T. (1996), Bacterial heavy metal resistance: New surprises. Annu. Rev. Microbiol., 50, 753-789.

Vecchio, A.; Finoli, C.; Di Simine, D. and Andreoni, V. (1998), Heavy metal biosorption by bacterial cells. Fresenius. J. Anal. Chem., 361, 338-342.

Watling, R. J. (1975), The determination of mercury at picogram/liter levels in water with a microwaveinduced argon plasma emission system. Anal. Chim. Acta., 75, 281-288.
Received: January 31, 2002; Revised: June 17, 2002;

Accepted: November 18, 2002. 